\title{
DIGITALISASI KOLEKSI KARYA SASTRA BALAI PUSTAKA SEBAGAI UPAYA PELAYANAN DI ERA DIGITAL NATIVES
}

\begin{abstract}
Mustofa
Abstrak

Digitalisasi adalah proses kegiatan mengubah dokumen tercetak menjadi dokumen digital. Proses digitalisasi ini dapat dilakukan terhadap berbagai bentuk koleksi atau bahan pustaka seperti, peta, naskah kuno, foto, karya seni patung, audio visual, lukisan, dan sebagainya. Balai Pustaka merupakan suatu angkatan dalam periodisasi sastra yang terkenal dengan sebutan angkatan pembangkit karena lahir pada masa kebangkitan sastra Indonesia yaitu pada periode tahun 1920 sampai tahun 1942. Tulisan ini membahas tentang masalah yang muncul dalam digitalisasi terutama tentang hak cipta, keuntungan digitalisasi, proses digitalisasi, dan contoh karya sastra Angkatan Balai Pustaka.
\end{abstract}

Kata kunci: Digitalisasi, Karya Sastra, Balai Pustaka, Digital Natives.

\section{PENDAHULUAN}

Pada acara pembukaan Book Fair di Benteng Vastenburg Surakarta tanggal 3-9 Mei 2016 yang dihadiri oleh Bapak Anis Baswedan selaku Menteri Pendidikan Nasional menyisakan cerita yang sangat menarik, pada saat dialog ada salah satu peserta yang merupakan penyandang difabel, kemudian mengutarakan uneg-unegnya tentang koleksi-koleksi karya sastra terutama karya sastra angkatan balai pustaka yang saat ini susah untuk ditemukan, kalaupun ada biasanya bukunya sudah dalam keadaan kumel, berdebu dan susah dijangkau oleh kaum difabel. Dia berharap kepada perpustakaan nasional untuk menyediakan karya-karya sastra tersebut dengan versi pdf atau $e$-book sehingga mudah diakses oleh masyarakat seluruh Indonesia.

Perpustakaan Nasional yang memiliki fungsi deposit seluruh karya yang dihasilkan seluruh penerbit di Indonesia. Pasal 10 ayat 1 dalam UU RI Nomor 4 Tahun 1990 Tentang Serah Terima Karya Cetak dan Karya Rekam diterangkan bahwa "Pengelolaan karya cetak dan karya rekam yang diserahkan untuk disimpan berdasarkan Undang-Undang ini dilakukan oleh Perpustakaan Nasional dan Perpustakaan Daerah yang menerimanya, atau badan lain yang ditetapkan oleh
Pemerintah dalam hal karya rekam yang berupa film ceritera atau dokumenter".

Dalam perkembangannya perpustakaan juga tidak lepas dari teknologi informasi. Tantangan baru teknologi informasi khususnya untuk para penyedia informasi adalah bagaimana menyalurkan informasi dengan cepat, tepat, akurat dan global. Perpustakaan sebagai salah satu penyedia informasi yang keberadaannya sangat penting di dunia pendidikan, mau tidak mau harus memikirkan kembali bentuk yang tepat untuk menjawab tantangan ini. Salah satunya adalah dengan mewujudkan perpustakaan digital yang terhubung dengan jaringan internet tentunya dengan menyediakan koleksi dalam bentuk digital. (Rasiman, 2011;1).

Bahan pustaka adalah salah satu unsur penting dalam sebuah sistem perpustakaan, sehingga harus dilestarikan mengingat nilainya yang mahal. Bahan pustaka di sini berupa terbitan buku, berkala (surat kabar dan majalah), dan bahan audiovisual seperti audio kaset, video, slide dan sebagainya. Pelestarian bahan pustaka tidak hanya menyangkut pelestarian dalam bidang fisik, tetapi juga pelestarian dalam bidang informasi yang terkandung di dalamnya.

\footnotetext{
* Pustakawan Perpustakaan ISI Surakarta

E-mail: mmustofa81@gmail.com
} 
Koleksi bagi perpustakaan merupakan salah satu faktor yang sangat penting untuk terselenggaranya layanan perpustakaan dengan baik. Keterbatasan anggaran untuk menambah koleksi di suatu perpustakaan merupakan masalah tersendiri bagi perpustakaan. Sedangkan kebutuhan akan informasi dari para pengguna semakin meningkat. Pengelolaan koleksi ini biasanya juga akan memunculkan berbagai masalah. Selain membutuhkan space yang luas karena pertambahannya yang cepat, pemeliharaannya juga memerlukan tenaga dan biaya yang relatif besar. Oleh karena itu pengalihan bentuk dari tercetak menjadi bentuk digital (digitalisasi) terhadap koleksi ini merupakan satu solusi untuk meminimalkan masalah dalam pengelolaannya, juga dapat meningkatkan mutu pelayanan di perpustakaan. Koleksi Karya Sastra khususnya terbitan Balai Pustaka yang jumlahnya ribuan yang dimiliki Perpustakaan Nasional sudah saatnya dialihmediakan atau digitalisasi sebagai bentuk dari pelestarian bahan pustaka maupun pelestarian informasi yang terkandung didalamnya. Mengingat koleksi-koleksi tersebut sudah tua umurnya dan sudah tidak diterbitkan, serta susah ditemukan di pasaran.

Zaman sekarang adalah era informasi, dan era informasi ini adalah era ter evolusinya segala hal. Kita bisa melihat evolusi politik dari sistem konvensional menuju digital. Generasi digital native mempunyai proses belajar yang sangat berbeda dibanding generasi digital immigrant. Generasi digital native "jengah" ketika disuruh membaca Encyclopedia Brittanica, tapi toh mereka tahu banyak hal. Hal ini bisa terjadi karena mereka selalu berpacaran dengan "Google" dan search engine lain. Kemampuan belajar mereka jauh lebih cepat karena segala informasi ada di ujung jari mereka.

\section{Problematika Hak Cipta}

Pada tahap perkembangan dan kemajuan suatu lembaga informasi termasuk juga perpustakaan dalam membangun infrastruktur jaringan elektronik atau digital dipengaruhi oleh beberapa faktor, yaitu:

1. Eksternalitas pada tingkat sosial, seperti penerapan hukum pada kekayaan intelektual (copyright), investasi dalam infrastruktur komunikasi nasional.

2. Keterbatasan lembaga dan organisasi lokal, seperti ketersediaan sumber daya, kebutuhan pengguna, kepemimpinan seseorang dalam mengatur organisasi.

3. Terobosan teknologi informasi mengubah kebiasaan sosial dan kerja dalam skala besar
Melalui penyediaan sumber-sumber informasi digital, perpustakaan dapat mengembangkan program yang memungkinkan para penggunanya untuk mengakses basis data perpustakaan. Mengingat pentingnya sumbersumber informasi digital ini sejumlah perpustakaan dalam beberapa tahun terakhir ini bekerja keras untuk meningkatkan kapasitas informasi elektronik atau digital mereka, apakah itu berupa jurnal elektronik (e-journal), $e$-theses, edisertations, atau buku-buku elektronik ( $e$ books) lainnya, baik yang disajikan secara utuh (full text) maupun sebagian (abstrak)-nya saja.

Dilihat dari segi legalitas dari suatu jenis ciptaan atau koleksi yang didigitalkan, Wahono (1999:3) menyebutkan ada beberapa faktor penghambat di antaranya:

1. Masalah mendigitalkan dokumen

Pembuatan perpustakaan digital tidak menemui masalah selama dokumen yang diterima berupa file elektronik. Masalah muncul pada saat dokumen yang diterima berupa file non-elektronik, misalnya berupa kertas atau buku. Proses pendigitalan koleksi tercetak agak rumit seperti halnya untuk mengubah format dari isi sumber aslinya, apakah akan diformat sebagian (abstrak) atau secara keseluruhan (full text).

2. Masalah hak cipta, yaitu:

a. Hak cipta pada dokumen yang didigitalkan. Kegiatan di dalamnya adalah mengubah dokumen tercetak ke dokumen digital, memasukkan dokumen digital ke database, mengubah dokumen digital ke format Hypertext Markup Language (HTML).

b. Hak cipta pada dokumen di jaringan komunikasi. Di dalam hukum hak cipta masalah transfer dokumen atau koleksi lewat jaringan komputer belum didefinisikan dengan jelas. Hal yang perlu disempurnakan adalah tentang hak menyebarkan, hak meminjamkan, hak memperbanyak, hak menyalurkan baik kepada masyarakat umum atau pribadi. Semua transfer datanya memanfaatkan media jaringan komputer termasuk di dalamnya internet, intranet, dan sebagainya.

c. Masalah penarikan biaya. Hal ini menjadi masalah terutama untuk perpustakaan digital swasta yang menarik biaya untuk setiap dokumen yang diakses maupun yang dicetak. Namun, dalam prakteknya perpustakaan juga sangat sulit untuk menerapkan peraturan hak cipta secara optimal.

Berkaitan dengan permasalahan di atas, Pendit (2007:166) mengatakan bahwa ketentuan hukum 
mengenai hak cipta adalah tidak adil bagi sebagian pihak, termasuk juga tidak adil bagi perpustakaan. Hal itu terjadi karena pihak perpustakaan beranggapan bahwa lembaga-lembaga informasi yang besar saja, seperti halnya penerbit buku dan agen-agen informasi ternama yang mengambil keuntungan terbanyak dari materi-materi yang dilindungi hak cipta, dan bukan para pencipta karya tersebut.

\section{Pengertian dan Perlunya Digitalisasi Koleksi}

Pengertian digitalisasi menurut Terry Kuny dalam Rasiman adalah "mengacu pada proses menerjemahkan suatu potongan informasi seperti sebuah buku, rekaman suara, gambar atau video, ke dalam bit-bit. Bit adalah satuan dasar informasi di dalam suatu sistem komputer. Sedangkan menurut Marilyn Deegan "digitalisasi adalah proses konversi dari segala bentuk dokumen tercetak atau yang lain ke dalam penyajian bentuk digital".

Dalam bidang perpustakaan, proses digitalisasi adalah kegiatan mengubah dokumen tercetak menjadi dokumen digital. Proses digitalisasi ini dapat dilakukan terhadap berbagai bentuk koleksi atau bahan pustaka seperti, peta, naskah kuno, foto, karya seni patung, audio visual, lukisan, dan sebagainya. Untuk mendigitalisasi masing-masing bentuk koleksi tersebut tentunya digunakan cara yang berbeda. Misalnya untuk karya seni patung dan lukisan, biasanya menggunakan kamera digital atau merekamnya dalam bentuk gambar bergerak sehingga menghasilkan foto digital atau video. Sedangkan untuk dokumen cetak lain biasanya menggunakan mesin scanner.

Menurut Wahyu Supriyanto, ada beberapa alasan mengapa bahan pustaka perlu di digitalisasi, yaitu:

1. Bahan-bahan pustaka seperti buku, skripsi, tesis, disertasi, jurnal ataupun artikel yang ada sangat dimungkinkan untuk tersedia dalam format digital (bukan kertas).

2. Dapat menghemat tempat penyimpanan

3. Bahan pustaka lebih aman dari kerusakan sehingga lebih tahan lama.

4. Jika dipasang pada Website dapat diakses oleh banyak orang dan dari mana pun.

\section{Tujuan Digitalisasi}

Perpustakaan Nasional sebagai penyedia layanan informasi harus memainkan peran untuk mampu meningkatkan kualitas layanan dengan mengembangkan koleksi elektronik. Untuk itu, kuantitas sumber daya informasi elektronik yang dimiliki harus diperbaharui salah satu caranya yaitu dengan mendigitalisasi koleksi Karya Sastra Balai Pustaka guna mendukung kebutuhan sumber bacaan serta kegiatan proses belajar mengajar dan penelitian pada semua elemen masyarakat. Deegen menjelaskan dalam bukunya Digital Futures (Deegan dan Tanner: 2002:23), ada beberapa keuntungan digitalisasi yaitu antara lain:

1. Akses cepat ke item permintaan tinggi dan sering digunakan

2. Akses mudah ke komponen individual dalam item (contoh: artikel dalam jurnal)

3. Akses cepat ke materi secara remote

4. Kemampuan untuk mendapatkan materi yang tidak diterbitkan lagi (out of print)

5. Berpotensi untuk menampilkan materi dalam format yang tidak dapat dicapai (contoh: ukuran terlalu besar atau peta)

6. Mengizinkan penyebaran koleksi dan digunakan secara bersama

7. Berpotensi untuk mempresentasikan benda yang mudah pecah/asli mahal dengan pengganti dalam format yang dapat diakses

8. Meningkatkan kemampuan penelusuran, termasuk full text

9. Integrasi pada media yang berbeda (gambar, suara, video, dll)

10. Mengurangi beban atau ongkos pengiriman

Dari uraian di atas dapat disimpulkan bahwa tujuan digitalisasi terhadap koleksi adalah untuk perluasan pemanfaatan dan kemudahan akses. Pemanfaatan dan akses terhadap sumber daya informasi elektronik jauh lebih luas jika dibandingkan dengan bahan tercetak. Sumber daya informasi elektronik dapat digunakan oleh banyak pengguna (multi user) dalam waktu yang bersamaan dan dapat dimanfaatkan dengan akses jarak jauh (remote access) tanpa harus datang ke perpustakaan. Pemanfaatan sumber daya informasi elektronik dapat dilakukan tidak hanya oleh pengguna dari internal institusi, akan tetapi juga oleh masyarakat luas, sekaligus berfungsi sebagai sosial kontrol apabila sumber daya tersebut dipublikasikan secara terbuka di internet. Melalui digitalisasi, perpustakaan dapat menyimpan ribuan bahkan jutaan karya local content maupun koleksi lainnya tanpa dibatasi ruang dan waktu. 


\section{Proses Digitalisasi Dokumen}

Menurut Syakirin Pangaribuan pengelolaan dokumen elektronik memerlukan teknik khusus yang memiliki perbedaan dengan pengelolaan dokumen tercetak. Proses pengelolaan dokumen elektronik melewati beberapa tahapan, yang dapat kita rangkumkan dalam proses digitalisasi, penyimpanan dan pengaksesan/temu kembali dokumen. Pengelolaan dokumen elektronik yang baik dan terstruktur adalah bekal penting dalam pembangunan sistem perpustakaan digital (digital library).

\section{Proses Digitalisasi Dokumen}

Proses perubahan dari dokumen tercetak (printed document) menjadi dokumen elektronik sering disebut dengan proses digitalisasi dokumen. Dokumen mentah (jurnal, prosiding, buku, majalah, dsb) diproses dengan sebuah alat (scanner) untuk menghasilkan dokumen elektronik. Proses digitalisasi dokumen ini tentu tidak diperlukan lagi apabila dokumen elektronik sudah menjadi standar dalam proses dokumentasi sebuah organisasi.

2. Proses Penyimpanan

Pada tahap ini dilakukan proses penyimpanan dimana termasuk didalamnya adalah pemasukan data (data entry), editing, pembuatan indeks dan klasifikasi berdasarkan subjek dari dokumen. Klasifikasi bisa menggunakan UDC (Universal Decimal Classification) atau DDC (Dewey Decimal Classification) yang banyak digunakan di perpustakaan-perpustakaan di Indonesia. Ada dua pendekatan dalam proses penyimpanan, yaitu pendekatan basis file (file base approach) dan pendekatan basis data (database approach). Masing-masing pendekatan memiliki kelebihan dan kelemahan, dan kita dapat memilih pendekatan mana yang akan kita gunakan berdasarkan kebutuhan.

3. Proses Pengaksesan dan Pencarian Kembali Dokumen

Inti dari proses ini adalah bagaimana kita dapat melakukan pencarian kembali terhadap dokumen yang telah kita simpan. Metode pengaksesan dan pencarian kembali dokumen akan mengikuti pendekatan proses penyimpanan yang kita pilih. Pendekatan database membuat proses ini lebih fleksibel dan efektif dilakukan, terutama untuk penyimpanan data sekala besar. Disisi lain, kelemahannya adalah relatif lebih rumitnya sistem dan proses yang harus kita lakukan.

\section{Uploading}

Uploading, adalah proses pengisian (input) metadata dan meng-upload berkas dokumen tersebut ke digital library. Berkas yang di-upload adalah berkas PDF yang berisi full text karya dari mulai halaman judul hingga lampiran, yang telah melalui proses editing. Karena bertujuan untuk diakses ke seluruh masyarakat Indonesia maka harus dibutuhkan sebuah server yang berhubungan dengan internet, yang berisi seluruh metadata dan full text karya yang dapat diakses oleh seluruh pengguna.

\section{Karakteristik Karya Sastra Balai Pustaka}

Sastra merupakan suatu kata yang sampai saat ini belum ada yang mampu menafsirkan secara tepat tentang pengertiannya, bahkan kata tersebut sampai saat ini masih menjadi bahan pertanyaan para ilmuan demi untuk mencari keselarasan pengertian yang tepat. Menurut Teeuw (2002: 23) kata sastra dalam bahasa Indonesia berasal dari bahasa sansekerta; akar kata sas- dalam kata kerja turunan berarti mengarahkan, mengajarkan, memberi petunjuk atau instruksi. Akhiran -tra biasanya menunjukkan alat, sarana. Maka, berdasarkan penggabungan tersebut sastra dapat berarti alat untuk mengajar, buku petunjuk, buku instruksi atau alat pengajaran.

Seperti yang telah kita ketahui, definisi karya sastra dalam Maimunah adalah "suatu karya yang mengandung nilai seni dan mengarah kepada pedoman-pedoman serta pemikiran-pemikiran hidup". Sedangkan Sastra Indonesia sendiri dapat merujuk pada sastra yang dibuat di wilayah Kepulauan Indonesia. Sering juga secara luas dirujuk kepada sastra berbahasa akarnya, yakni bahasa melayu.

Sastra di Indonesia sudah ada sejak dulu sekali bahkan mungkin sudah ada sejak zaman purbakala dimana manusia-manusia purba memulai untuk menggambar dan menulis sesuatu di dalam gua-gua, sehingga menghasilkan karya-karya sastra. Tetapi karya-karya tersebut kemudian menghilang karena perkembangan zaman yang mungkin kurang maju. "Angkatan Balai Pustaka" ini muncul setelah "Angkatan Sastra Melayu Lama" yang muncul antara sekitar tahun 1870-1942.

Menurut Sarwadi dalam Maimunah "Balai Pustaka mempunyai pengaruh terhadap perkembangan sastra Indonesia yaitu dengan keberadaannya maka sastrawan Indonesia dapat melontarkan apa yang menjadi beban 
pikirannya melalui sebuah tulisan yang dapat dinikmati oleh dirinya sendiri dan juga orang lain (penikmat sastra)". Balai Pustaka mempunyai tujuan untuk memberikan konsumsi berupa bacaan kepada rakyat yang berisi tentang politik pemerintahan kolonial, sehingga dengan hal itu Balai Pustaka telah memberikan informasi tentang ajaran politik kolonial. Berdasarkan pernyataan tersebut maka dengan didirikannya Balai Pustaka telah memberikan manfaat kepada rakyat Indonesia karena sastra Indonesia menjadi berkembang.

Balai Pustaka merupakan suatu angkatan dalam periodisasi sastra yang terkenal dengan sebutan angkatan pembangkit karena lahir pada masa kebangkitan sastra Indonesia yaitu pada periode tahun 1920 sampai tahun 1942. Namun Balai Pustaka juga dikenal sebagai nama sebuah penerbit yang memang keberadaannya menunjang penerbitan sastra-sastra pada masa itu. Melihat kenyataan tersebut maka karakteristik yang membedakan sastra angkatan Balai Pustaka dengan sastra angkatan lainnya adalah: karya-karyanya kebanyakan bertemakan kawin paksa, memuat pertentangan paham antara kaum tua dengan kaum muda, unsur nasionalitas yang terkandung dalam karya sastra belum jelas, peristiwa yang diceritakan hanya merupakan realitas kehidupan, analisis psikologi dalam karya sastra masih kurang, karya-karya angkatan Balai Pustaka bersifat didaktis, bahasa yang digunakan adalah bahasa melayu umum, serta yang paling membedakan sastra angkatan Balai Pustaka dengan angkatan lainnya yaitu genre asil karyanya berupa novel, pantun dan syair.

Angkatan Balai Pustaka bisa disebut masa dimana proses modernisasi karya-karya sastra terjadi. Dimana tidak lagi terpaut oleh budaya-budaya melayu yang kental. Balai Pustaka merupakan suatu angkatan yang sangat berpengaruh kepada perkembangan perpustakaan baru terutama yang tertulis dengan huruf latin (Usman, 1979: 15). Hal itu tercermin dengan pindahnya pusat perhatian orang-orang yang berminat kepada kesusastraan ke Balai Pustaka (Jakarta) yang berpengaruh pada perkembangan bahasa dari bahasa melayu baru (yang banyak dipengaruhi oleh bahasa-bahasa daerah dan bahasa surat kabar) kemudian menjelma menjadi bahasa Indonesia.

Jadi, dapat disimpulkan bahwa dengan munculnya angkatan Balai Pustaka maka telah membuka hati para penulis untuk mau memperlihatkan hasil karyanya yang dulunya menggunakan bahasa daerah kemudian beralih menggunakan bahasa Indonesia sebagai ungkapan rasa bangga berbangsa Indonesia. Selain itu, dengan munculnya angkatan Balai Pustaka maka telah membuka semangat dan kesadaran para penulis untuk

mempersatukan daerah-daerahnya demi keutuhan bangsa Indonesia. Disisi lain Balai Pustaka juga dikenal sebagai nama suatu penerbit besar yang berdiri pada sekitar tahun 1920an yang pada tahun tersebut beriringan dengan munculnya angkatan Balai Pustaka. Munculnya angkatan Balai Pustaka memang disesuaikan dengan karya-karya besar yang terkenal pada waktu itu yang sebagian besar diterbitkan dari penerbit Balai Pustaka Jakarta.

Berbicara mengenai periodisasi sastra khususnya Balai Pustaka maka tidak menutup kemungkinan kalau meninjau tentang keadaan sosial pada tahun 1920an, dimana menurut Teeuw (1980: 15) pada tahun tersebut merupakan tahun lahirnya kesusastraan Indonesia modern. Pada waktu itu para pemuda Indonesia mulai menyatakan perasaan dan ide yang berbeda dengan masyarakat setempat. Perasan itu dituangkan dalam bentuk sastra namun menyimpang dari bentuk sastra melayu, jawa, dan sastra-sastra lain sebelumnya.

Pada masa ini bahasa Melayu Riau dipandang sebagai bahasa Melayu standar yang lebih baik dari dialek-dialek Melayu lain seperti Betawi, Jawa, atau Sumatera. Oleh karena itu, para lulusan sekolah asal Minangkabau, yang diperkirakan lebih mampu mempelajari bahasa Melayu Riau, dipilih sebagai dewan redaksi. Beberapa diantaranya adalah Armjin Pane dan Alisjahbana. Angkatan Balai Poestaka baru mengeluarkan novel pertamanya yang berjudul Azab dan Sengsara karya Merari Siregar pada tahun 1920-an. Novel yang mengangkat fenomena kawin paksa pada masa itu menjadi tren baru bagi dunia sastra. Novel-novel lain dengan tema serupa pun mulai bermunculan. Adapun ciri-ciri karya sastra pada masa Balai Poestaka, yaitu:

1. Gaya Bahasa

2. Alur

3. Tokoh

4. Pusat Pengisahan

5. Terdapat digresi

6. Corak

7. Sifat

8. Latar belakang sosial : Pertentangan paham antara kaum muda dengan kaum tua.

9. Peristiwa yang diceritakan sesuai dengan realitas kehidupan masyarakat. 
Tabel 1. Tokoh dan hasil karya sastra Balai Pustaka

\begin{tabular}{|c|c|c|}
\hline No & Nama & Hasil Karya \\
\hline 1 & $\begin{array}{l}\text { Nur Sutan Iskandar } \\
\text { (Lahir di Maninjau tahun } \\
\text { 1893) }\end{array}$ & $\begin{array}{l}\text { Karangan asli } \\
\text { Salah pilih (dikarang dengan nama samaran Nur Sinah tahun 1928), Karena Mertua } \\
\text { (tahun 1932), Hulubalang Raja (novel sejarah oleh Teeuw dipandang yang terbaik), } \\
\text { Katak Hendak Jadi lembu, Neraka Dunia (1973), Cinta tanah Air (novel yang terbit } \\
\text { pada jaman Jepang tahun1944), Mutiara (1946), Cobaan (1947), Cinta dan Kewajiban } \\
\text { (dikarang bersama dengan I.Wairata). } \\
\text { Karangan terjemahan } \\
\text { Anjing Setan - A. Canon Doyle, Gidang Intan Nabi Sulaiman - Rider Haggard, Kasih } \\
\text { Beramuk dalam Hati - Beatrice Harraday, Tiga Panglima Perang - Alexander Dumas, } \\
\text { Graaf De Monto Cristo - Alexander Dumas, Iman dan Pengasihan - H Sien Klewiex, } \\
\text { Sepanjang Gaaris kehidupan - R Casimir. } \\
\text { Karangan saduran } \\
\text { Pengajaran Di Swedwn - Jan Lightair, Pengalaman Masa Kecil - Jan Lighard, Pelik- } \\
\text { pelik Kehidupan - Jan Lighard, Si Bakil - Moliere Lavare, Abu Nawas, Jager Bali, } \\
\text { Korban Karena Penciiptaan, Apa Dayaku karena Aku Seoarng Perempuan, Dewi } \\
\text { Rimba } \\
\text { Catatan harian } \\
\text { Ujian Masa (21-7-1947 s/d 1-4-1948) }\end{array}$ \\
\hline 2 & Abdul Muis & $\begin{array}{l}\text { Hasil karyannya : Salah Asuhan (1928), Pertemuan Jodoh (1933), Suropati (1950) - } \\
\text { novel sejarah, Robert Anak suropati (1953) - novel sejarah, Sebatang Kara (Hector } \\
\text { Mallot) - karangan terjemahan. }\end{array}$ \\
\hline 3 & $\begin{array}{l}\text { Marah Rusli } \\
\text { Lahir di Padang } 7 \text { Agustus } \\
1989 \text { dan meninggal di } \\
\text { Bandung } 17 \text { Januari } 1968\end{array}$ & $\begin{array}{l}\text { Karya-karyanya: Siti Nurbaya (1922) - Sub judul Kasih Tak Sampai, Anak dan } \\
\text { Kemenakan (1956), Memang Jodoh - La Harni (1952). }\end{array}$ \\
\hline 4 & $\begin{array}{l}\text { Aman Datuk Majaindo } \\
\text { Lahir di Solok pada tahun } \\
1896 .\end{array}$ & $\begin{array}{l}\text { Karya-karyanya: Si Doel Anak Betawi (cerita anak-anak), Anak Desa (cerita anak- } \\
\text { anak), Si Cebol Rindukan Bulan (1934), Menebus Dosa, Perbuatan Dukun - Rusmala } \\
\text { dewi (dikarang bersama S. Harja Sumarta), Sebabnya Rapiah Tersesat (1934), Syair } \\
\text { Si Banso (Gadis Durhaka) terbit tahun 1931 - Kumpulan Syair, Syair Gul Bakawali } \\
\text { (1936) - Kumpulan Syair. }\end{array}$ \\
\hline 5 & $\begin{array}{l}\text { Muhammad Kasim } \\
\text { Lahir tahun } 1886\end{array}$ & $\begin{array}{l}\text { Karya-karyanya : Pemandangan Dunia Anak-anak, Teman Dukun (kumpulan cerpen), } \\
\text { Muda Terung, Pengeran Hindi, Niki Bahtera. }\end{array}$ \\
\hline 6 & Tulis Sutan Sati & $\begin{array}{l}\text { Hasil karyanya: } \\
\text { Karangan yang berbentuk novel: Tidak Membalas Guna (1932), Memutuskan } \\
\text { Pertalian (1932), Sengsara Membaaw Nikmat (1928). } \\
\text { - Cerita lama yang disadur dalam bentuk syair: Siti Marhumah yang Saleh, Syair } \\
\text { Rosida. } \\
\text { - Hikayat lama yang ditulis kembali dalam bentuk prosa liris:Sabai Nan Aluih }\end{array}$ \\
\hline 7 & $\begin{array}{l}\text { Selasih dan Sa'adah Alim } \\
\text { Lahir tahun } 1909\end{array}$ & $\begin{array}{l}\text { Karya-karyanya: Kalau Tak Ujung (1933), Pengaruh Keadaan (1973). Sa'adam Alim } \\
\text { Karya-karyanya: Pembalasannya (1941) - sebuah sandiwara, Taman Penghibur } \\
\text { Hati (1941) - kumpulan cerpen, Angin Timur angina Barat (Preal S. Buck) - karya } \\
\text { terjemahan. }\end{array}$ \\
\hline 8 & Merari Siregar & Hasil karyanya: Azab dan Saengsara (1920) \\
\hline 9 & $\begin{array}{l}\text { I Gusti Njoman Pandji } \\
\text { Tisna }\end{array}$ & $\begin{array}{l}\text { Karya-karyanya: Ni Rawi Ceti Penjual Orang (1935), I Swasta Setahun di Bedahulu } \\
\text { (1941), Sukreni Gadis Bali, Dewi Karuna (1938), I Made Widiadi (Kembali Kepada } \\
\text { Tuhan) }\end{array}$ \\
\hline
\end{tabular}




\begin{tabular}{lll}
\hline No & \multicolumn{1}{c}{ Nama } & \multicolumn{1}{c}{ Hasil Karya } \\
\hline 10 & Paulus Supit & Hasil karyanya: Kasih Ibu (1932) \\
\hline 11 & Suman H.S & Karya-karyanya: Kasih Tak Terlarai (1929), Percobaan Saetia (1931), Mencari Pencuri \\
& Lahir di Bengkalis, & Anak Perawan (1932), Kawan Bergelut (1938) - Kumpulan Cerpen. \\
\hline
\end{tabular}

10. Puisinya berbentuk syair dan pantun.

11. Menggambarkan tema pertentangan paham antara kaum tua dan kaum muda, soal pertentangan adat, soal kawin paksa, permaduan, dll.

12. Soal kebangsaan belum mengemuka, masih bersifat kedaerahan.

\section{Tokoh-Tokoh Angkatan Balai Pustaka Beserta Hasil Karyanya}

Menurut Rosidi (1986: 37) tokoh-tokoh yang termasuk dalam angkatan Balai Pustaka dapat dilihat pada tabel 1 .

\section{Pelayanan di Era Digital Natives}

Dewasa ini, digitalisasi merupakan suatu tuntutan dalam pemberian jasa layanan perpustakaan untuk mendapatkan informasi yang aktual, akurat, dan sesuai dengan kebutuhan pengguna. Permadi (16-17) mengatakan bahwa "untuk mencapai hasil yang optimal dalam upaya memajukan perpustakaan, maka pengelola perpustakaan mempunyai pedoman antara lain perpustakaan harus selektif dan mempunyai kemampuan":

1. Mengetahui pengguna/user setempat dan informasi yang diperlukan

2. Menyediakan koleksi yang relevan dan akurat

3. Mengusahakan layanan jasa pada saat diperlukan

4. Memotivasi pengguna/user untuk mengoptimalkan fasilitas yang ada diperpustakaan.

Pemakai perpustakaan (user) di Perpustakaan Nasional sebagian besar adalah mahasiswa. Persoalan revolusi informasi dan masalah yang berkaitan dengan ledakan informasi semua akan terfokus di sekeliling pemakai. Bahkan keberhasilan sistem informasi sangat tergantung bagaimana sistem tersebut mempertimbangkan secara tepat apa dan bagaimana karakter pemakainya. Dengan demikian, dalam sistem informasi pemakai merupakan seseorang yang tidak dapat diabaikan jika sistem informasi tersebut diharapkan berhasil.

Perpustakaan sebagai lembaga yang mengelola sumber informasi dan pelestari bahan pustaka hasil budaya bangsa perlu dipersiapkan dan dikelola dengan baik, agar dapat diwujudkan sistem perpustakaan yang komprehensif yang bermuara pada kepuasan pengguna. Saat ini, perpustakaan tidak lagi berorientasi pada teknis pengolahan bahan pustaka, akan tetapi berorientasi kepada pemakai. Perpustakaan yang berorientasi kepada pemakai akan selalu membuat produk yang terbaru, sumber daya manusia yang profesional, serta memberikan pelayanan yang terbaik untuk pemakainya. Tantangan perpustakaan di era global ini antara lain harus mampu meningkatkan kemampuan dan mengikuti perkembangan kebutuhan informasi yang berkualitas sehingga dapat memenuhi kebutuhan pengguna sesuai harapannya.

Dengan demikian, perpustakaan tidak lagi hanya berperan sebagai tempat penyimpanan buku dan memberikan layanan peminjaman buku, akan tetapi sudah menjadikan informasi yang dimiliki sebagai komoditi yang dapat memenuhi kebutuhan masyarakat. Dari sinilah perpustakaan dapat menunjukkan eksistensi dan perannya dalam menghadapi era informasi global. A. PH. Permadi (18-19).

\section{KESIMPULAN}

Sastra di Indonesia sudah ada sejak dulu sekali bahkan mungkin sudah ada sejak zaman purbakala dimana manusia-manusia purba memulai untuk menggambar dan menulis sesuatu di dalam gua-gua, sehingga menghasilkan karya-karya sastra. Tetapi karya-karya tersebut kemudian menghilang karena perkembangan zaman yang mungkin kurang maju. "Angkatan Balai Pustaka" ini muncul setelah "Angkatan Sastra Melayu Lama" yang muncul antara sekitar tahun 1870-1942.

Dewasa ini, digitalisasi merupakan suatu tuntutan dalam pemberian jasa layanan perpustakaan untuk mendapatkan informasi yang aktual, akurat, dan sesuai dengan kebutuhan pengguna. Perpustakaan Nasional sebagai penyedia layanan informasi harus memainkan peran untuk mampu meningkatkan kualitas layanan dengan mengembangkan koleksi elektronik. Untuk itu, kuantitas sumber daya informasi elektronik yang dimiliki 
harus diperbaharui salah satu caranya yaitu dengan mendigitalisasi koleksi Karya Sastra Balai Pustaka guna mendukung kebutuhan sumber bacaan serta kegiatan proses belajar mengajar dan penelitian pada semua elemen masyarakat.

\section{DAFTAR PUSTAKA}

Deegan, Marilyn [and] Simon Tanner. 2002. Digital Futures: strategies for the information age. London: Library Association Publishing.

Maimunah, Makalah Sejarah Sastra, dalam https:// maimunahh.wordpress.com/2015/01/01/makalahsejarah-sastra/, diunduh pada tanggal 21 Juli 2018.

Pendit, Putu Laxman. 2007. Perpustakaan Digital: Perspektif Perpustakaan Perguruan Tinggi Indonesia. Jakarta: CV. Sagung Seto.

Permadi, dalam http://e-journal.uajy.ac.id/7545/2/thesis1.pdf, diunduh pada tanggal 21 Juli 2018.

Rasiman, Digitalisasi Local Content: ONTENT: Perluasan Pemanfaatan dan Akses Layanan Perpustakaan. Disampaikan pada Seminar dan Workshop Pemberdayaan Repositori Perpustakaan Untuk
Meningkatkan Mutu dan Pelayanan Perpustakaan, Diselenggarakan oleh Panitia Seminar Nasional Forum Komunikasi Perpustakaan Medan, Universitas HKBP Nommensen, 1 Desember 2011.

Rosisdi, Ajip. 1986. Ikhtisar Sejarah Sastra Indonesia. Yogyakarta: Kurnia Kalam Semesta.

Syakirin Pangaribuan, Pengelola Perpustakaan Digital. Disampaikan pada Seminar Perpustakaan Digital Institut Agama Islam Negeri (IAIN) Sumatera Utara Medan, 26 Juli 2010. dalam http://dokumen.tips/ documents/pengelolaan-perpustakaan-digital.html, diunduh pada tanggal 21 Juli 2018.

Teeuw, A. 2002. Sastra dan Ilmu Sastra. Yoyakarta: Universitas Negeri Yoyakarta

Usman, Zuber. 1979. Kesusastraan Baru Indonesia. Jakarta: Gunung Agung.

Wahono, Romi Satria. Digital Library dan Proyek-Proyek Penelitiannya, dalam Jurnal DIMENSI: Warta Sains dan Teknologi, Vol.2, No.1, Juli 1999.

Wahyu Supriyanto, Digitalisasi Koleksi Perpustakaan Prospek dan Kendala, dalam http://old.lib.ugm.ac.id/ data/pubdata/pusta/wahyus.pdf, diunduh pada tanggal 21 Juli 2018. 